\title{
Effect of Public Investment on Private Investment and Economic Growth: Evidence From Vietnam by Economic Industries
}

\author{
Nguyen Thi Canh ${ }^{1} \&$ Nguyen Anh Phong ${ }^{2}$ \\ ${ }^{1} \mathrm{PhD}$, Prof, University of Economics and Law-Vietnam National University-Ho Chi Minh City (VNU-HCM), Vietnam \\ ${ }^{2} \mathrm{PhD}$ in Finance, University of Economics and Law-Vietnam National University- Ho Chi Minh City, Vietnam \\ Correspondence: Nguyen Thi Canh, PhD, Prof, University of Economics and Law-Vietnam National University-Ho Chi \\ Minh City (VNU-HCM), Vietnam.
}

Received: January 19, 2018

doi:10.11114/aef.v5i2.2998 doi:10.11114/aef.v5i2.2998

\author{
Accepted: February 3, $2018 \quad$ Available online: February 6, 2018 \\ URL: https://doi.org/10.11114/aef.v5i2.2998
}

\begin{abstract}
This study is to assess the impact of public investment on private investment and economic growth in Vietnam based on data from 22 economic industries over a 27-year period (1990-2016) by applying PVAR model combined with GMM. The results show that public investment and state sector investment (including public investment and state-owned enterprise investment for production and business activities) has the same positive impact economic growth in most economic industries in the long term, but state sector investment also creates more growth effects in the short term. Public investment has a cyclical impact on private capital stock (domestic private + FDI capital stock) and FDI investment; it has the effect of boosting domestic private investment, FDI investment in the short and long term. Meanwhile, state-sector investment has decreased the private capital stock in the short term, crowds out domestic private and FDI investments in the short term, and in the long term. Both public investment and state sector investment has the effect of increasing public debt in the long term. Based on these results we have some policy recommendations to increase efficiency of public investment and state sector investment.
\end{abstract}

Keyword: public investment, state sector investment, private investment, economic growth JEL Code: O00

\section{Introduction}

Vietnam has achieved satisfactory results after implementing innovative economic policies for 30 years which records a stable and higher growth rate than that of the nations in the Southeast Asia region for years. Vietnam economy is now integrating into the global economy, improving fiscal policy (Budget revenue and expenditure suits the economy scale and overspending rate is in allowed restriction) which creates trust for international investors and sponsor organizations. Since 2007, Vietnam became an official member of World Trade Organization (WTO); and since early 2016, Vietnam has been a member of ASEAN Economic Community (AEC), Vietnam has been step by step cutting tariffs as integrated commitment. Tax reduction means a part of budget income through tax will decrease, and a sharp drop in crude oil price also leads to decreased budget income. However, Vietnam Government needs to maintain public expenses for social- economic and infrastructure development, which is far too weak. In the context of high budget pressures, the need to save government expenses is set. However, in order to achieve economic growth and improve the competitiveness of the economy to attract private domestic investment and foreign direct investment (FDI), it is necessary to improve the investment and business environment. To improve the investment and business environment, the role of government is to provide public goods and services through investment in technical infrastructure (e.g., roads, bridges, ports, industrial parks, and so on) and social infrastructure (e.g., hospital, school, and so on). It is therefore necessary to increase public investment by the government, and public investment must ensure efficiency by attracting private investment and economic growth.

There are two opposite trends in public investment research. As for the first trend, many studies in developing countries have evidence that public investment positively affects private investment and economic growth (Bukhari, Ali and Saddaqat (2007); Zainah, P. (2009); Haque S. (2013) and etc.). As for the second trend which has the opposite result to the first one, the results of studies in developed countries indicate that public investment crowd out public investment and has little or no impact on economic growth; Moreover, it even has opposite effect on economic growth (Vedder and 
Gallaway (1998)). Dreger and Reimers (2014 and 2016) acknowledged that in the short run public investment has no impact on economic growth but in the long run is impacted.

Within the scope of this research, we would like to consider whether public investment in Vietnam has a positive effect, i.e. public investment has an impact on attracting private investment and economic growth or not. The questions to be answered in this study are: What is the role of public investment in Vietnam today? What is the impact of public investment on attracting private investment and economic growth?

In answering the above questions, the study will assess the impact of public investment on attracting private investment and economic growth and testing hypotheses on whether public investment is crowding out or crowding in the private investment in Vietnam.

\section{Literature Review}

The theory that explains the relationship between inputs and growth in a national product is called the production function. The production function is one of the key concepts of mainstream neoclassical theories, used to define marginal product and to distinguish allocated efficiency, the defining focus of economics. Cobb-Douglas production function (1928) represent the technological relationship between the amounts of two or more inputs, particularly physical capital $(\mathrm{K})$ and labor $(\mathrm{L})$, and the amount of output $(\mathrm{Y})$ that can be produced by those inputs. Robert Solow (1956) tried to explain the origin of growth by a different kind of production function that allows analysis of the different causes or origins of growth called the Solow model. The main assumptions of the Solow model relate to the characteristics of the production function and the evolution of the three inputs of product (capital, labor and knowledge) over time.

Public investment which affects strongly to economic growth is also reflected by aggregate supply and demand. Public investment directly impacts on aggregate demand as a government expenditure and aggregate supply as a production function (capital factor). Public investment has spillover effect and indirectly impacts to aggregate demand by stimulating private investment and to aggregate supply through attracting private investment.

Investigation about effect of public investment on private investment has had series of studies done in many countries and has the opposite results. Studies showing the positive effects of public investment on private investment appear to be frequency and often occur in developing countries or emerging economies. The study on the effect of public investment on private investment in developing economies was done by Erden, L., \& Holcombe, R. $(2005,2006)$ has a result indicating that public investment crowds in private investment. Hanato, T. (2010) has a study investigating the effects of public investment on private investment based on Japanese empirical data. Estimating the error correction model, the author affirmed that the crowding-in effect of public investment on private investment. Gjini, A., \& Kukeli, A. (2012) have a study in crowding - out effect of public investment on private investment in transition economies in Eastern Europe. The result of this study showed that there was no crowding-out effect of public investment on private investment. The study of Foye, V. (2014) in Nigeria showed that public investment is motivation of private investment growth. Dreger and Reimers (2016) have a study to answer a question "Does public investment stimulate private investment in the euro area" and indicated that the lack of public investment may have restricted private investment and thus GDP growth in the euro area. In addition to the above-mentioned studies that have resulted in the positive effects of public investment on private investment (public investment stimulates private investment); there are also some studies that show the negative effects of public investment (public investment crowds out private investment). The study of Cruz and Teixeira (1999), indicated that private investment is crowded out by public investment in short term, but in the long term these two variables complement each other. Erden, L. and Holcombe, R. (2005) indicated that public investment has positive affect private investment in developing economies, whereas, public investment has a negative affect private investment in developed countries. Gjini. A. and Kukeli, A. (2012) showed that there is a crowd-out effect of public investment on private investment in Western countries, but it does not in Eastern European Countries.

A comprehensive study of the effects of public investment on private investment and economic growth has also been carried out in different countries and groups of countries, and results are not quite the same. Cullison, E.W. (1993) applied VAR model to evaluate linkage between public investment and economic growth. The results indicated that Government consumptions for Education and Labor training have clear effects on economic Growth in future. Hsieh and Lai, N (1994) used endogenous growth model by Barro (1990) to examine the relationship between government consumption and economic growth for the Group-of-Seven countries (G7). The empirical results suggest that the relationship between government spending and growth can vary significantly over time as well as across the major industrialized countries. Most importantly, there is no clear evidence that government spending can increase GDP per capita GDP in G7. Khan, M. and Kumar, M. (1996 and 1997) indicated that the private investment has a much stronger impact than public sector investment. There is a difference between public investment and private investment in areas. For Africa and the Middle East, both types of investment exercised a similar impact, while in Latin America public 
investment appeared to have had, on average, very limited impact and private investment with a pronounced positive effect. In Asia, public investment was statistically significant, but had an effect on growth only about half that of private investment. Ramirez and Nazmi's (1997 and 2003) studies on public investment and economic growth in Latin America with using OLS and data for the period (1983-1993) showed that the openness of economy, human capital and government consumption/ public health significantly affect private investment. Research results also indicated that both private investment and public investment contribute to economic growth. Ghani, E., \& Din, M. (2006) have studied the impact of public investment on economic growth in Pakistan with using the vector autoregressive approach (VAR). The VAR consists of four variables including public investment, private investment, public consumption and GDP with data from 1973 to 2004. The result showed that economic growth is largely driven by private investment and that no strong inference can be made about the effects of public investment and public consumption on economic growth. The results also showed the presence of long run causality from public investment, private investment, and public consumption to economic growth. Syed et al. (2007) examined the casual connection between public investment and economic growth in the Three Little Dragons (Korea, Singapore, and Taiwan) using a variety of econometric techniques with Heterogeneous Dynamic Panel Data in the period $(1971$ - 2000). The authors also used four variables model that includes public investment, public consumption, private investment and growth rate of GDP. The results indicated that both public and private investment and public consumption have a long term dynamic impact on economic growth and the pair-wise analysis showed bidirectional causality between public investment and economic growth in all the countries. Swaby, R. (2007), investigated the relationship between public investment and growth in Jamaica, with using VECM. The Granger causality result suggested that public investment does not cause GDP; however, GDP causes public investment. The VECM showed that in the long-run domestic private investment, FDI, and the REER all have a positive statistically significant direct impact on the level of GDP. Public investment has the effect of crowding - out net private investment. Gregoriou, A., \& Ghosh, S. (2008), have a study on the impact of government expenditure on growth for 15 developing countries. Using GMM techniques, the authors showed that countries with substantial government expenditure have strong growth effects.

Zainah, P. (2009), investigated the role of public investment in promoting economic growth in Mauritius, used dynamic econometric framework, and Vector Autoregressive (VAR) model. The link between public capital, as measured by transport and communication infrastructure and economic performance has been analyzed in a multivariate dynamic framework. Results from this analysis revealed that both transport and communication infrastructure is important elements promote the Mauritian economy. Phetsavong and Ichihashi (2012), analyze the factors affecting economic growth and the interrelationship of public investment, FDI, and private domestic investment using a panel data covering the period $1984-2009$. The study found that both public investment and private domestic investment positively affect economic growth. Kumo, W. (2012) conducted pairwise Granger causality tests between infrastructure investment and economic growth in South Africa for the period 1960-2009 using bivariate vector auto-regression (VAR) model with and without a structural break. The author found that there is a strong causality between infrastructure investment and GDP growth that run in both directions implying that infrastructure investment drives the long term economic growth in South Africa while improved growth feeds back into more public infrastructure investments. Haque, S. (2013) used the new neo-classical growth model of Cobb- Douglas production function utilizing the error correction model (ECM). The findings of the study concluded that there exist a short-run and long-run relationship between public and private investment and economic growth in Bangladesh.

In Vietnam, there have been some studies on the impact of public investment on economic growth but mainly on qualitative or theoretical descriptions and not much empirical research. Recently there have been a few empirical studies on public investment and economic growth in Vietnam. To T. T. (2011) used the error correcting vector model (VECM) to estimate responses to public, private investment and GDP variables for the period 1986-2010. The result showed that both of private investment and public investment positively influence output, and be statistically significant, but private investment is stronger. Tran N.N.A. and Le H.P. (2014) used autoregressive distributed lag model (ARDL) to examine the effects of public investment on Vietnam economic growth for the period $1988-2012$. The result indicated that the effect of public investment on economic growth in short term is not statistically significant, but it promotes long - run growth. However, these empirical studies in Vietnam are limited in data sources, and the authors used public investment including investment from state-owned enterprises (SOEs) for production and business activities. Under Public Investment Law of Vietnam in 2014, public investment includes (i) investment in socio-economic infrastructure programs and projects; (ii) investment in the operation of state agencies and non-business units, political organizations, socio-political organizations in the country and abroad; (iii) investing and supporting the provision of public utility products and services (public goods).

Our research will inherit international research and overcome the limitations of some researches in Vietnam, including (1) replacing some variables with Vietnamese characteristics; (2) separating public investment from production and business investment of SOEs; (3) analyzing the impact of public investment by industry. 
In addition to the above differences, for the convenience of comparison with previous studies we have also apply the model with variable "state sector investment", including public investment and state-owned enterprise (SOE's) investment for production and business. Further research on "state sector investment" variable can help to compare the impact of public investment and the impact of state sector investment on private investment and economic growth.

\section{Research Method, Model and Data}

In this study, the authors use research variables to assess the interactive relationship between public investment and private investment and economic growth, along with other macro variables, according to studies done by Khan, M., \& Kumar, M. (1997), Ghani, E., \& Din, M. (2006), Phetsavong and Ichihashi (2012) or Zainah, P. (2009).

Unlike previous studies, they were using the VAR method as studied by Cullison, E.W. (1993), Hsieh, E. and Lai, N. (1994), Ghani, E., \& Din, M. (2006), Zainah, P. (2009) or study by Kumo, W. (2012), our study used the PVAR method for panel data on 22 economic industries from 1990 to 2016.

Panel VARs are designed to capture both static and dynamic interdependencies across countries or regions using some set of restrictions, treat the linkages across units, and can account for cross sectional heterogeneities (Canova and Cicarelli, (2013)). According to Abrigo and Love (2015), estimation and inference of homogeneous panel VAR models in a generalized method of moments (GMM) framework, by using standard Stata datasets.

Under the subdivision of the General Statistics Office of Vietnam, the whole economy is classified into 22 primary industries (see appendix). Thanks to the support of experts from the Capital Management Department of the General Statistics Office, public investment data are extracted from the data of public sector investment by primary economic industries/sectors. The total set of data table in our study including a sample of 594 observations is suitable for applying PVAR.

The difference in this study compared to previous studies is that previous studies analyzed a country's series data or panel data for a group of countries, while our study analyzed panel table data by economic industries/sectors. As mentioned, public investment is the investment of the state in projects to build socio-economic infrastructure and investment in programs and projects for socio -economic development. Therefore, most of the economic industries/ sectors in Vietnam have public investment in the infrastructure of the industry/ sector development as well as for economic development in general. However, according to figures published by the General Statistics Office of Vietnam, investment capital data are broken down into three categories: the state sector investment, the private sector investment, and foreign sector investment. State sector investment includes public investment in socio-economic infrastructure construction and state-owned enterprise investment for production and business activities. So to analyze the impact of public investment, we split the total investment into four categories: public investment; Investment of SOEs for production and business activities; domestic private investment; and foreign investment. The investment capital of each kind is calculated on average for one year. In addition to investment capital for one year, it is possible to add capital stock of private sectors, includes domestic private capital stock and foreign capital stock. Data of capital stock can be obtained from IMF and WB source, which is calculated in US dollars. Because data are from two sources of IMF/WB and General Statistics Office of Vietnam, we transferred data from the General Statistics Office of Vietnam in the local currency (Vietnam dong) to the data in US dollars. In addition to the investment and GDP variables, in the research model, there were a number of other macro variables, such as real interest rates, public debt and the openness of the economy. The variables used in this study are described in the following table 1.

Table 1. Describe the variables used in the model

\begin{tabular}{|c|c|c|c|}
\hline Variable name & Notation & Data Source & Unit \\
\hline $\begin{array}{l}\text { Public investment for } \mathrm{i} \text { economic } \\
\text { industry at year } \mathrm{t}\end{array}$ & $\mathrm{GI}_{\mathrm{it}}$ & GSO; Converted at the annual average exchange rate & $\begin{array}{l}\text { Billion } \\
\text { USD }\end{array}$ \\
\hline GDP of $\mathrm{i}$ economic industry in the year $\mathrm{t}$ & $\mathrm{Y}_{\mathrm{it}}$ & GSO; Converted at the annual average exchange rate & $\begin{array}{l}\text { Billion } \\
\text { USD }\end{array}$ \\
\hline $\begin{array}{l}\text { SOE's investment in } \mathrm{i} \text { economic } \\
\text { industry at the year t }\end{array}$ & $\mathrm{GEI}_{\mathrm{it}}$ & GSO; Converted at the annual average exchange rate & $\begin{array}{l}\text { Billion } \\
\text { USD }\end{array}$ \\
\hline $\begin{array}{l}\text { Domestic private investment in } \mathrm{i} \\
\text { economic industry at the year } \mathrm{t}\end{array}$ & $\mathrm{PEI}_{\mathrm{it}}$ & GSO; Converted at the annual average exchange rate & $\begin{array}{l}\text { Billion } \\
\text { USD }\end{array}$ \\
\hline $\begin{array}{l}\text { Foreign investment in } \mathrm{i} \text { economic } \\
\text { industry at the year } \mathrm{t}\end{array}$ & $\mathrm{FDI}_{\mathrm{it}}$ & GSO; Converted at the annual average exchange rate & $\begin{array}{l}\text { Billion } \\
\text { USD }\end{array}$ \\
\hline $\begin{array}{l}\text { Real interest fixed for } \mathrm{i} \text { economic } \\
\text { industry at the year } \mathrm{t}\end{array}$ & $\mathrm{RR}_{\mathrm{it}}$ & WB & $\%$ \\
\hline $\begin{array}{l}\% \text { of public debt to GDP fixed for } \mathrm{i} \\
\text { economic industry at the year } \mathrm{t}\end{array}$ & Debt $_{i t}$ & $\begin{array}{l}\text { GSO; Converted public debt and GDP into USD at the } \\
\text { annual average exchange rate and calculated ratio }\end{array}$ & $\%$ \\
\hline $\begin{array}{l}\text { Economic Openness fixed for } \mathrm{i} \\
\text { economic industry at the year } \mathrm{t}\end{array}$ & Open $_{\text {it }}$ & GSO; total of export and import to GDP & $\%$ \\
\hline $\begin{array}{l}\text { Private capital stock fixed for i } \\
\text { economic industry at the year t }\end{array}$ & $\mathrm{PRCS}_{\mathrm{it}}$ & IMF & $\begin{array}{l}\text { Billion } \\
\text { USD }\end{array}$ \\
\hline
\end{tabular}


Research model with PVAR method (a panel VAR framework) for assessing the impact of public investment on private investment and economic growth is a set of the following equations (with optimal expectation of lag and difference of order 1):

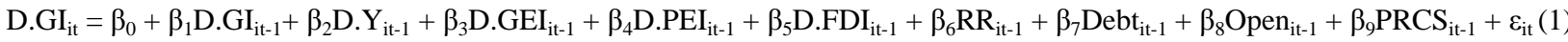

$$
\begin{aligned}
& \text { D. } Y_{\mathrm{it}}=\beta_{0}+\beta_{1} \text { D.GI } \mathrm{GI}_{\mathrm{i}-1}+\beta_{2} \mathrm{D} \text {. } Y_{\mathrm{it}-1}+\beta_{3} \mathrm{D} \cdot \mathrm{GEI}_{\mathrm{it}-1}+\beta_{4} \mathrm{D} \cdot \mathrm{PEI}_{\mathrm{it}-1}+\beta_{5} \mathrm{D} \cdot \mathrm{FDI}_{\mathrm{it}-1}+\beta_{6} \mathrm{RR}_{\mathrm{it}-1}+\beta_{7} \mathrm{Debt}_{\mathrm{it}-1}+\beta_{8} \mathrm{Open}_{\mathrm{it}-1}+\beta_{9} \mathrm{PRCS}_{\mathrm{it}-1}+\varepsilon_{\mathrm{it}}
\end{aligned}
$$

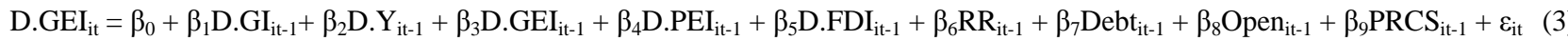

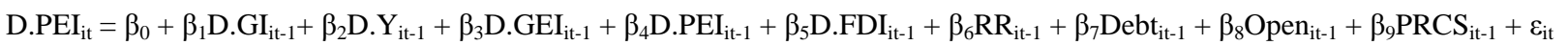

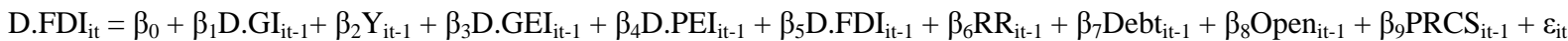

Where:

$\beta$ is Coefficient of marginal impact between variables; D. () is the year-to-year difference of order $1 ; \varepsilon$ is the contingent error.

As stated above, to answer the question of whether there is a difference in the impact of public investment and state sector investment, we applied another model with variable "state sector investment", including public investment and state-owned enterprise investment (SOE) for production and business activities. Thus, in addition to analyzing the impact of public investment on private investment and economic growth by industries above, in this case we would like to consider how public/state sector investment (as previous studies have done by some authors) including public investment and SOE investments affect private investment and economic growth by industries in Vietnam. Thus, the two variables of public investment and SOEs' investment in production and business are replaced by one variable- the state sector investment. The number of variables considered in this second case is shown in Table 2

Table 2. Description of variables used in Case 2 (state sector investment)

\begin{tabular}{|c|c|c|c|}
\hline Variable name & Notation & Data Source & Unit \\
\hline $\begin{array}{l}\text { State sector investment for i economic } \\
\text { industry at year } \mathrm{t}\end{array}$ & $\mathrm{I}_{\mathrm{it}}$ & GSO; Converted at the annual average exchange rate & $\begin{array}{l}\text { Billion } \\
\text { USD }\end{array}$ \\
\hline $\begin{array}{l}\text { GDP of } i \text { economic industry in the } \\
\text { year } t\end{array}$ & $\mathrm{Y}_{\mathrm{it}}$ & GSO; Converted at the annual average exchange rate & $\begin{array}{l}\text { Billion } \\
\text { USD }\end{array}$ \\
\hline $\begin{array}{l}\text { Domestic private investment in } \mathrm{i} \\
\text { economic industry at the year } \mathrm{t}\end{array}$ & $\mathrm{PEI}_{\mathrm{it}}$ & GSO; Converted at the annual average exchange rate & $\begin{array}{l}\text { Billion } \\
\text { USD }\end{array}$ \\
\hline $\begin{array}{l}\text { Foreign investment in } \mathrm{i} \text { economic } \\
\text { industry at the year } \mathrm{t}\end{array}$ & $\mathrm{FDI}_{\mathrm{it}}$ & GSO; Converted at the annual average exchange rate & $\begin{array}{l}\text { Billion } \\
\text { USD }\end{array}$ \\
\hline $\begin{array}{l}\text { Real interest fixed for } \mathrm{i} \text { economic } \\
\text { industry at the year } \mathrm{t}\end{array}$ & $\mathrm{RR}_{\mathrm{it}}$ & WB & $\%$ \\
\hline $\begin{array}{l}\% \text { of public debt to GDP fixed for i } \\
\text { economic industry at the year } t\end{array}$ & Debt $_{\text {it }}$ & $\begin{array}{l}\text { GSO; Converted public debt and GDP into USD at the } \\
\text { annual average exchange rate and calculated ratio }\end{array}$ & $\%$ \\
\hline $\begin{array}{l}\text { Economic Openness fixed for } \mathrm{i} \\
\text { economic industry at the year } \mathrm{t}\end{array}$ & Open $_{\text {it }}$ & GSO; total of export and import to GDP & $\%$ \\
\hline $\begin{array}{l}\text { Private capital stock fixed for } \mathrm{i} \\
\text { economic industry at the year } \mathrm{t}\end{array}$ & PRCS $_{\text {it }}$ & IMF & $\begin{array}{l}\text { Billion } \\
\text { USD }\end{array}$ \\
\hline
\end{tabular}

As the number of variables decreases by 1 , the number of equations in this section will decrease to 4 . As in the previous section, the PVAR research model examines the impact of public/state sector investment on private investment and economic growth is a system of four following equations (with optimal expectation of lag and difference of order 1):

$$
\begin{aligned}
& \mathrm{I}_{\mathrm{it}}=\beta_{0}+\beta_{1} \mathrm{I}_{\mathrm{it}-1}+\beta_{2} \text { D. } Y_{\mathrm{it}-1}+\beta_{3} \text { D.PEI } \mathrm{PE}_{\mathrm{it}-1}+\beta_{4} \mathrm{D}_{\mathrm{DPDI}} \mathrm{it}-1_{1}+\beta_{5} \mathrm{RR}_{\mathrm{it}-1}+\beta_{6} \text { Debt }_{\mathrm{it}-1}+\beta_{7} \text { Open }_{\mathrm{it}-1}+\beta_{8} \text { PRCS }_{\mathrm{it}-1}+\varepsilon_{\mathrm{it}}
\end{aligned}
$$

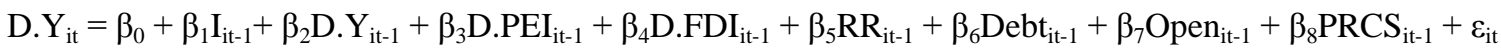

$$
\begin{aligned}
& \text { D.PEI }{ }_{i t}=\beta_{0}+\beta_{1} I_{i t-1}+\beta_{2} \text { D. } Y_{i t-1}+\beta_{3} \text { D.PEI } I_{i t-1}+\beta_{4} \text { D.FDI }_{i t-1}+\beta_{5} R_{\text {Rt }-1}+\beta_{6} \text { Debt }_{\text {it }-1}+\beta_{7} \text { Open }_{i t-1}+\beta_{8} \text { PRCS }_{\text {it }-1}+\varepsilon_{i t} \\
& \text { D.FDI }{ }_{i t}=\beta_{0}+\beta_{1} I_{i t-1}+\beta_{2} Y_{i t-1}+\beta_{3} \text { D.PEI } I_{i t-1}+\beta_{4} \text { D.FDI }_{i t-1}+\beta_{5} R_{\text {Rt }-1}+\beta_{6} \text { Debt }_{i t-1}+\beta_{7} \text { Open }_{i t-1}+\beta_{8} \text { PRCS }_{\text {it }-1}+\varepsilon_{i t}
\end{aligned}
$$

Where:

$\beta$ is Coefficient of marginal impact between variables

D.() is the year-to-year difference of order 1

$\varepsilon$ is the contingent error 


\section{Research Results}

4.1 The Results of the Model Studying the Impact of Public Investment on Private Investment and Economic Growth (Case 1)

Table 3 shows statistical results describing variables from research data. The results show that GI, Y, GEI, PEI and FDI variables are normal, while other macroeconomic variables such as RR, Debt, Open, and PRCS have some abnormalities. The real interest rate (RR) has an average value of $-2.89 \%$, the min value is $-62.6 \%$ and the max value is $12.58 \%$, or the debt to GDP ratio in average is $94.07 \%$, the min value is $11.5 \% . \%$ and the max value $450.6 \%$. These abnormal results stemmed from the shock of the start of the opening economy (from 1990 to 1995). At this stage, the macro-economic policy was not good, the inflation rate hiked so that the real interest rate with negative figure was too high. At the same time, at this stage, Vietnam was a low-income country while government debt was mainly the debt owed by the former Soviet Union and the Russian-dollar Rupee exchange rate has not changed over a long period, this led to a high public debt / GDP ratio. After this period, Vietnam reached an agreement with the Russian Federation to change the - rupee -dollar exchange rate, to restructure its debt, and to get a debt reduction. Thus, the debt-to-debt ratio declined significantly after 1995 .

Table 3. Descriptive statistics of the variables (case 1- study on the impact of public investment)

\begin{tabular}{l|l|l|l|l|l}
\hline Variable & Obs & Mean & Std. Dev & Min & Max \\
\hline gi & 594 & .2233 & .4695 & 0 & 3.2736 \\
\hline y & 594 & 3.2560 & 5.6700 & .0114 & 34.8746 \\
\hline gei & 594 & .2547 & .4960 & .0003 & 4.233 \\
\hline pei & 594 & .3986 & .6217 & .0003 & 3.7325 \\
\hline fdi & 594 & .2553 & .8646 & 0 & 9.7906 \\
\hline rr & 594 & -2.8966 & 17.8001 & -62.6 & 12.58 \\
\hline debt & 594 & 94.0733 & 105.8785 & 11.5 & 450.6 \\
\hline open & 594 & 110.4626 & 40.2356 & 45.31 & 170.07 \\
\hline prcs & 594 & 226.2593 & 155.4563 & 44 & 543.75 \\
\hline
\end{tabular}

Source: Author's calculations from Stata15

In addition, the above analysis table describing the statistics of the variables shows that the standard deviation is greater than the mean value, so that most variables exhibit varying variance. In order to overcome this phenomenon, the author uses a combination of PVAR integrated with GMM according to the study done by Abrigo and Love (2015).

By using integrated GMM with PVAR, to ensure that data is stationary, the author applies fisher-type to test stationary of variables according to Abrigo and Love (2015). Test results are shown in Table 4.

Table 4. Test results of the stationary of the variables

\begin{tabular}{|c|c|c|}
\hline Variable & P-value & Stationary/Non-stationary \\
\hline D.GI ${ }_{\text {it }}$ & 0.000 & stationary \\
\hline D. $Y_{i t}$ & 0.000 & stationary \\
\hline D.GEI $_{\text {it }}$ & 0.000 & stationary \\
\hline D.PEI ${ }_{i t}$ & 0.000 & stationary \\
\hline $\mathrm{FDI}_{\mathrm{it}}$ & 0.025 & stationary \\
\hline $\mathrm{RR}_{\mathrm{it}}$ & 0.000 & stationary \\
\hline Debt $_{\text {it }}$ & 0.000 & stationary \\
\hline Open $_{\text {it }}$ & 0.000 & stationary \\
\hline D2.PRCS $_{\text {it }}$ & 0.000 & stationary \\
\hline
\end{tabular}

Source: Author's calculations from Stata15

The above results (Table 4) show that the GI, Y, GEI, PEI variables are stationary at the difference of order 1, while the FDI, RR, Debt, Open variables are stationary but PRCS variable is stationary at difference of order 2, so ensuring that to apply the PVAR integration with GMM is appropriate.

Table 5. The result of optimal lag length selection

\begin{tabular}{l|l|l|l|l|l|l}
\hline lag & CD & J & J p-value & MBIC & MAIC & MQIC \\
\hline 1 & .8543 & 216.6844 & $1.10 \mathrm{e}-15$ & -242.9943 & 66.6844 & -55.2715 \\
\hline 2 & .9934 & 168.8238 & $5.85 \mathrm{e}-15$ & -136.6287 & 69.8238 & -11.4801 \\
\hline 3 & .9990 & 129.1856 & $5.15 \mathrm{e}-16$ & -24.0401 & 79.1855 & 38.5335 \\
\hline
\end{tabular}

Source: Author's calculations from Stata15

The seeking result of lag length using in the model shows that the optimal lag is 1 because at this level the MBIC, MAIC and MQIC values are min (Table 5). 
The results of Granger-causality co-integration test of variables are statistically significant, indicating that almost all variables have interaction effects (excepting for those variables that are not statistically significant such as RR effects and Debt to GI or impact of GI to FDI) (See Appendix 2). This result is appropriate for assessing the interaction effect between variables using in the PVAR model.

According to Kao, C. (1999), residual-based tests for co-integration regression in panel data is to apply Dickey Fuller (DF) tests and an augmented Dickey Fuller (ADF) to test the null of no co-integration. The result of co-integration test is shown in Table 6.

Table 6. The Result of Co-integration Test

Source: Author's calculations from Stata15

\begin{tabular}{l|c|c}
\hline & Statistic & p-value \\
\hline Modified Dickey-Fuller t & -37.48 & 0.00 \\
Dickey- Fuller t & -25.21 & 0.00 \\
Augmented Dickey- Fuller t & -17.09 & 0.00 \\
Unadjusted Modified Dickey-Fuller t & -37.48 & 0.00 \\
Unadjusted Dickey- Fuller t & -25.21 & 0.00 \\
\hline
\end{tabular}

(*) Statistics those are significant at $1 \%$ level

Table 7. Estimation results of model using PVAR combined with GMM

\begin{tabular}{|c|c|c|c|c|c|}
\hline Model & \multicolumn{2}{|c|}{ Variables } & Coef & Std.Err & $\mathrm{P}>|\mathrm{Z}|$ \\
\hline \multirow[t]{9}{*}{ (1) } & D.GI $_{\text {it }}$ & D.GI ${ }_{\text {it-1 }}$ & -0.616 & 0.007 & $0.000^{(*)}$ \\
\hline & & D. $Y_{\mathrm{it}-1}$ & 0.119 & 0.001 & $0.000^{(*)}$ \\
\hline & & D.GEI $_{\text {it-1 }}$ & 0.011 & 0.002 & $0.000^{(*)}$ \\
\hline & & D.PEI ${ }_{\mathrm{it}-1}$ & -0.212 & 0.004 & $0.000^{(*)}$ \\
\hline & & $\mathrm{FDI}_{\mathrm{it}-1}$ & -0.258 & 0.002 & $0.000^{(*)}$ \\
\hline & & $\mathrm{RR}_{\mathrm{it}-1}$ & 0.000 & 0.001 & $0.000^{(*)}$ \\
\hline & & Debt $_{\text {it-1 }}$ & 0.000 & 0.000 & $0.002(*)$ \\
\hline & & Open $_{\text {it-1 }}$ & 0.001 & 0.000 & $0.000^{\left({ }^{*}\right)}$ \\
\hline & & D2.PRCS ${ }_{\text {it-1 }}$ & 0.005 & 0.000 & $0.000^{(*)}$ \\
\hline \multirow[t]{9}{*}{ (2) } & D.Y $_{\text {it }}$ & D. $Y_{\text {it-1 }}$ & 0.893 & 0.009 & $0.000^{(*)}$ \\
\hline & & D.GI $\mathrm{it}^{-1}$ & -0.362 & 0.024 & $0.000^{(*)}$ \\
\hline & & D. GEI $_{\text {it- } 1}$ & 1.721 & 0.021 & $0.000^{(*)}$ \\
\hline & & D.PEI ${ }_{\mathrm{it}-1}$ & 5.508 & 0.074 & $0.000^{(*)}$ \\
\hline & & FDI $_{\text {it-1 }}$ & -1.996 & 0.006 & $0.000^{(*)}$ \\
\hline & & $\mathrm{RR}_{\mathrm{it}-1}$ & -0.004 & 0.000 & $0.000^{(*)}$ \\
\hline & & Debt $_{\text {it-1 }}$ & -0.001 & 0.000 & $0.000^{(*)}$ \\
\hline & & Open $_{\text {it-1 }}$ & -0.004 & 0.000 & $0.000^{(*)}$ \\
\hline & & D2.PRCS ${ }_{\mathrm{it}-1}$ & -0.051 & 0.001 & $0.000^{(*)}$ \\
\hline \multirow[t]{9}{*}{ (3) } & D.GEI $_{\text {it }}$ & D. $Y_{\text {it }-1}$ & -0.208 & 0.012 & $0.000^{(*)}$ \\
\hline & & D. $\mathrm{GI}_{\mathrm{it}-1}$ & 0.865 & 0.014 & $0.000^{(*)}$ \\
\hline & & D.GEI $_{\text {it-1 }}$ & -0.013 & 0.008 & $0.000^{(\pi)}$ \\
\hline & & D.PEI $_{\mathrm{it}-1}$ & 2.528 & 0.031 & $0.000^{(*)}$ \\
\hline & & $\mathrm{FDI}_{\mathrm{it}-1}$ & 0.250 & 0.003 & $0.000^{(*)}$ \\
\hline & & $\mathrm{RR}_{\mathrm{it}-1}$ & -0.001 & 0.004 & $0.000^{(\pi)}$ \\
\hline & & Debt $_{\text {it }-1}$ & -0.005 & 0.000 & $0.000^{(*)}$ \\
\hline & & Open $_{\text {it-1 }}$ & -0.002 & 0.001 & $0.000^{(*)}$ \\
\hline & & D2.PRCS $_{\text {it-1 }}$ & -0.024 & 0.000 & $0.000^{(*)}$ \\
\hline \multirow[t]{9}{*}{ (4) } & D.PEI $_{i t}$ & D. $Y_{\mathrm{it}-1}$ & -0.066 & 0.001 & $0.000^{(*)}$ \\
\hline & & D. GI ${ }_{i t-1}$ & 0.456 & 0.007 & $0.000(*)$ \\
\hline & & D.GEI $_{\mathrm{it}-1}$ & 0.086 & 0.003 & $0.000^{(*)}$ \\
\hline & & D.PEI ${ }_{\text {it-1 }}$ & 0.993 & 0.015 & $0.000^{(*)}$ \\
\hline & & $\mathrm{FDI}_{\mathrm{it}-1}$ & 0.004 & 0.001 & $0.000^{(\pi)}$ \\
\hline & & $\mathrm{RR}_{\mathrm{it}-1}$ & -0.001 & 0.000 & $0.000^{(*)}$ \\
\hline & & Debt $_{\text {it-1 }}$ & -0.000 & 0.000 & $0.000^{(*)}$ \\
\hline & & Open $_{\text {it-1 }}$ & 0.001 & 0.000 & $0.000^{(*)}$ \\
\hline & & $\mathrm{PRCS}_{\mathrm{it}-1}$ & -0.004 & 0.000 & $0.000(*)$ \\
\hline \multirow[t]{9}{*}{ (5) } & $\mathbf{F D I}_{\text {it }}$ & D. $Y_{\text {it-1 }}$ & -0.063 & 0.001 & $0.000^{(n)}$ \\
\hline & & D. GI ${ }_{i t-1}$ & 0.623 & 0.009 & $0.000^{(*)}$ \\
\hline & & D.GEI $_{\mathrm{it}-1}$ & 0.011 & 0.004 & $0.000^{(*)}$ \\
\hline & & D.PEI ${ }_{i t-1}$ & 1.681 & 0.018 & $0.000^{(*)}$ \\
\hline & & $\mathrm{FDI}_{\mathrm{it}-1}$ & 0.901 & 0.002 & $0.000^{(*)}$ \\
\hline & & $\mathrm{RR}_{\mathrm{it}-1}$ & 0.001 & 0.000 & $0.000^{(*)}$ \\
\hline & & Debt $_{\text {it-1 }}$ & 0.001 & 0.000 & $0.000^{(*)}$ \\
\hline & & Open $_{\text {it-1 }}$ & -0.000 & 0.000 & $0.001^{(*)}$ \\
\hline & & D2.PRCS ${ }_{\mathrm{it}-1}$ & -0.001 & 0.000 & $0.000(*)$ \\
\hline
\end{tabular}


Source: Author's calculations from Stata15

Note: * Statistics those are significant at $1 \%$ level; ** Statistics those are significant at 5\% level.; *** Statistics those are significant at $10 \%$ level; D.(x) is difference of order $\mathrm{x}$ of variables.

Co-integration Test is applying Kao (1999) for all variables. The results of co-integration test are significant, indicating that almost all variables have interaction effects in short and medium terms event in the long terms (Table 6). This result is appropriate for assessing the interaction effect between variables using in the PVAR model.

The PVAR results show that all the variables are statistically significant. The results of beta coefficients in Table 7 show that in the short run $(<=1$ year $)$, economic growth in the previous period has a strong influence on economic growth of the next period, public investment has a negative impact on economic growth (in short-term under 1 year) while private investment and SOE investments are positively correlated to economic growth. Public investment has a positive impact on attracting private investment in and FDI investment.

To see causal effects in the short, medium and long term, we can see the figure of impulse response function (figure 1).

The results from the impulse response function (Figure 1) show the effect of public investment on private investment, economic growth and on other variables for the following conclusions:

+ Public investment increases the amount of private capital stock (including domestic private and FDI capital stock) in both medium and long term

+ Public investment helps increase the economy's openness in the long term.

+ Public investment increases the public debt ratio in the long term

+ In the long run, public investment has the effect of reducing the real interest rate

+ In the long term, public investment has the effect of boosting FDI investment

+ Public investment increases investment of SOEs in business and production in the short-term and long term

+ Public investment promotes economic growth in almost all sectors/industries in the medium and long term.

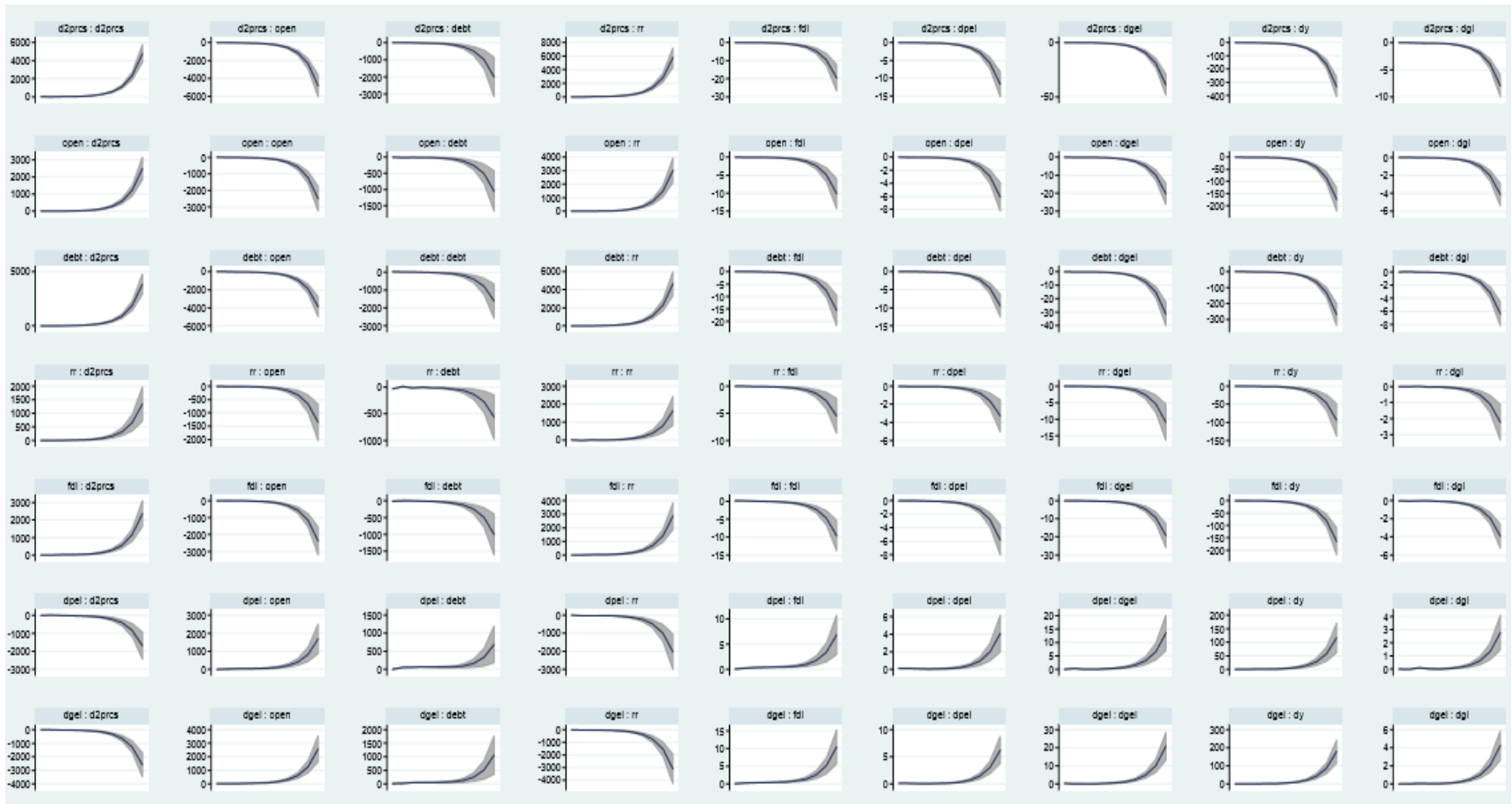

Figure 1. Impulse Response Functions (IRF)

Source: Author's calculations from Stata15

4.2 The Results of the Model Studying the Impact of State Sector Investment on Private Investment and Economic Growth (Case 2)

Table 8 describes the statistical data from research data showing that variables I, Y, PEI, and FDI are normal, while groups of other macro variables such as RR, Debt, Open, and PRCS have the same abnormalities as in case 1 above. 
Table 8. Descriptive statistics of the variables (case 2- study on the impact of state sector investment)

\begin{tabular}{l|l|l|l|l|l}
\hline Variable & Obs & Mean & Std. Dev & Min & Max \\
\hline $\mathrm{I}$ & 594 & .4781 & .7500 & .0008 & 4.3244 \\
\hline $\mathrm{y}$ & 594 & 2.2560 & 5.6700 & .0114 & 34.8746 \\
\hline pei & 594 & .3985 & .6217 & .0002 & 3.7325 \\
\hline $\mathrm{fdi}$ & 594 & .2552 & .8646 & 0 & 9.7906 \\
\hline $\mathrm{rr}$ & 594 & -2.8966 & 17.8001 & -62.6 & 12.58 \\
\hline debt & 594 & 94.0733 & 105.8785 & 11.5 & 450.6 \\
\hline open & 594 & 110.4626 & 40.2356 & 45.31 & 170.07 \\
\hline prcs & 594 & 226.2593 & 155.4563 & 44.18 & 543.75 \\
\hline
\end{tabular}

Source: Author's calculations from Stata15

In addition, Table 8 describing the statistics of the variables shows that the standard deviation is greater than the mean value, so that most variables exhibit varying variance. To overcome this phenomenon, as in case 1 above, the author applied a combination of the PVAR method integrated with the GMM according to Abrigo and Love (2015).

For case 2, the Fisher-type to test stationary of variables was also employed according to Abrigo and Love (2015). Test results are shown in Table 9.

Table 9. Test results of the stationary of the variables (case 2)

\begin{tabular}{|c|c|c|}
\hline Variable & P-value & Stationary/Non-stationary \\
\hline D. I $_{\text {it }}$ & 0.000 & stationary \\
\hline D. $Y_{\text {it }}$ & 0.000 & stationary \\
\hline D.PEI ${ }_{i t}$ & 0.000 & stationary \\
\hline $\mathrm{FDI}_{\mathrm{it}}$ & 0.025 & stationary \\
\hline $\mathrm{RR}_{\text {it }}$ & 0.000 & stationary \\
\hline Debt $_{\text {it }}$ & 0.000 & stationary \\
\hline Open $_{\text {it }}$ & 0.000 & stationary \\
\hline D2.PRCS $S_{\text {it }}$ & 0.000 & stationary \\
\hline
\end{tabular}

Source: Author's calculations from Stata15

The results of Table 9 show that I, Y, PEI variables are stationary at the difference of order 1, while the RR, Debt, Open variables are stationary, but PRCS is stationary at the difference of order 2. So ensuring that PVAR integration with GMM is appropriate

Table 10. The result of optimal lag length selection (case 2)

\begin{tabular}{c|r|r|r|r|r|r}
\hline lag & \multicolumn{1}{|c|}{ CD } & \multicolumn{1}{c|}{ J } & \multicolumn{1}{c|}{ J p-value } & \multicolumn{1}{c}{ MBIC } & \multicolumn{1}{c}{ MAIC } & \multicolumn{1}{c}{ MQIC } \\
\hline 1 & .9952 & 379.175 & $2.18 \mathrm{e}-14$ & -798.8534 & -4.8249 & -317.4402 \\
\hline 2 & .9889 & 199.5081 & .00005 & -585.8442 & -56.4918 & -264.902 \\
\hline 3 & .9998 & 93.8265 & .00893 & -298.8496 & -34.1735 & -138.3786 \\
\hline
\end{tabular}

Source: Author's calculations from Stata15

The seeking result of lag length using in the model case 2 also shows that the optimal lag is 1 because at this level the MBIC, MAIC and MQIC values are min (Table 10).

The results of Granger-causality Test of variables are statistically significant (See Appendix 3), but for the long run co-integration, we want to have a co-integration test.

Table 11. The Result of Co-integration Test

\begin{tabular}{|c|c|c|}
\hline & Statistic & p-value \\
\hline Modified Dickey-Fuller t & -40.61 & 0.00 \\
\hline Dickey- Fuller t & -28.76 & 0.00 \\
\hline Augmented Dickey- Fuller t & -16.04 & 0.00 \\
\hline Unadjusted Modified Dickey-Fuller t & -40.61 & 0.00 \\
\hline Unadjusted Dickey- Fuller t & -28.76 & 0.00 \\
\hline
\end{tabular}

Source: Author's calculations from Stata15

(*) -Statistics those are significant at $1 \%$ level

Co-integration Test is applying Kao (1999) for all variables. The results are likely with the case 1 when all of variables are significant (Table 11). This result is appropriate for assessing the interaction effect between variables using in the PVAR model. 
Table 12. Estimation results of model using PVAR combined with GMM (case 2)

\begin{tabular}{|c|c|c|c|c|c|}
\hline Model & \multicolumn{2}{|c|}{ Variables } & Coef & Std.Err & $\mathrm{P}>|\mathrm{Z}|$ \\
\hline \multirow[t]{8}{*}{ (1) } & D.I $_{\text {it }}$ & D.I it-1 $_{1}$ & -0.043 & 0.001 & $0.000^{(*)}$ \\
\hline & & D. $Y_{\mathrm{it}-1}$ & -0.062 & 0.000 & $0.000^{(*)}$ \\
\hline & & D.PEI $_{\text {it-1 }}$ & 2.102 & 0.000 & $0.000^{(*)}$ \\
\hline & & $\mathrm{FDI}_{\mathrm{it}-1}$ & -0.020 & 0.004 & $0.000^{(*)}$ \\
\hline & & $\mathrm{RR}_{\mathrm{it}-1}$ & -0.001 & 0.000 & $0.000^{(*)}$ \\
\hline & & Debt $_{\text {it-1 }}$ & 0.000 & 0.001 & $0.000^{(*)}$ \\
\hline & & Open $_{\text {it-1 }}$ & -0.001 & 0.000 & $0.000^{(*)}$ \\
\hline & & D2.PRCS ${ }_{\text {it- } 1}$ & -0.018 & 0.000 & $0.000^{(*)}$ \\
\hline \multirow[t]{8}{*}{ (2) } & D. $Y_{\text {it }}$ & D. $Y_{i t-1}$ & 0.943 & 0.021 & $0.000^{(*)}$ \\
\hline & & D. I $_{\mathrm{it}-1}$ & 1.565 & 0.039 & $0.000^{(*)}$ \\
\hline & & D.PEI ${ }_{i t-1}$ & 4.523 & 0.131 & $0.000^{(*)}$ \\
\hline & & $\mathrm{FDI}_{\mathrm{it}-1}$ & -0.243 & 0.014 & $0.000^{(*)}$ \\
\hline & & $\mathrm{RR}_{\mathrm{it}-1}$ & -0.003 & 0.001 & $0.000^{(*)}$ \\
\hline & & Debt $_{\text {it-1 }}$ & -0.001 & 0.000 & $0.000^{(*)}$ \\
\hline & & Open $_{\text {it-1 }}$ & -0.003 & 0.000 & $0.000^{(*)}$ \\
\hline & & D2.PRCS ${ }_{\text {it-1 }}$ & -0.046 & 0.001 & $0.000^{(*)}$ \\
\hline \multirow[t]{8}{*}{ (3) } & D.PEI $_{\text {it }}$ & D. $Y_{i t-1}$ & -0.029 & 0.002 & $0.000^{(*)}$ \\
\hline & & D. $\mathrm{I}_{\mathrm{it}-1}$ & 0.022 & 0.005 & $0.000(*)$ \\
\hline & & D.PEI ${ }_{\text {it- } 1}$ & 0.440 & 0.019 & $0.000(*)$ \\
\hline & & $\mathrm{FDI}_{\mathrm{it}-1}$ & -0.014 & 0.001 & $0.000^{(*)}$ \\
\hline & & $\mathrm{RR}_{\mathrm{it}-1}$ & -0.000 & 0.000 & $\underline{0.298}$ \\
\hline & & Debt $_{\text {it-1 }}$ & 0.000 & 0.000 & $\overline{0.168}$ \\
\hline & & Open $_{\text {it-1 }}$ & 0.000 & 0.000 & $0 . \overline{000^{(*)}}$ \\
\hline & & D2.PRCS $_{\text {it-1 }}$ & -0.003 & 0.000 & $0.000(*)$ \\
\hline \multirow[t]{8}{*}{ (4) } & FDI $_{\text {it }}$ & D. $Y_{\text {it-1 }}$ & -0.003 & 0.002 & $0.000^{(*)}$ \\
\hline & & D. $\mathrm{I}_{\mathrm{it}-1}$ & -0.099 & 0.004 & $0.000^{(*)}$ \\
\hline & & D.PEI $_{\text {it-1 }}$ & 0.773 & 0.021 & $0.000^{(*)}$ \\
\hline & & $\mathrm{FDI}_{\mathrm{it}-1}$ & 0.868 & 0.004 & $0.000^{(*)}$ \\
\hline & & $\mathrm{RR}_{\mathrm{it}-1}$ & 0.001 & 0.002 & $0.000^{(*)}$ \\
\hline & & Debt $_{\text {it-1 }}$ & 0.000 & 0.000 & $0.07^{(* *)}$ \\
\hline & & Open $_{\text {it-1 }}$ & 0.001 & 0.000 & $0.000^{(*)}$ \\
\hline & & D2.PRCS $\mathrm{it}_{\mathrm{it}-1}$ & -0.001 & 0.000 & $0.000(*)$ \\
\hline
\end{tabular}

Source: Author's calculations from Stata15

$(*),(* *),(* * *)$ Statistics those are significant at 1\% level, 5\% level, and $10 \%$ level

D. $(\mathrm{x})$ is difference of order $\mathrm{x}$ of variables.

The PVAR results show that almost the variables are statistically significant, exception of RR and Debt variables in the model (3), suggesting that real interest rate and short term debt do not affect state sector investment and domestic private investment. The results of model estimations in Table 12 also show that in the short-term $(<=1$ year $)$ state sector investment (including public investment and SOE investments) and domestic private investment has a positive impact on economic growth while FDI inflow investment has a negative impact on economic growth (perhaps in less than one year net FDI investment, imports of equipment and materials did not generate income): State-sector investment has an impact to stimulate domestic private investment, but it crowds out FDI investment.

To see causal effects in the short and medium term, we can see the figure of impulse response function for case 2 (figure 2). 


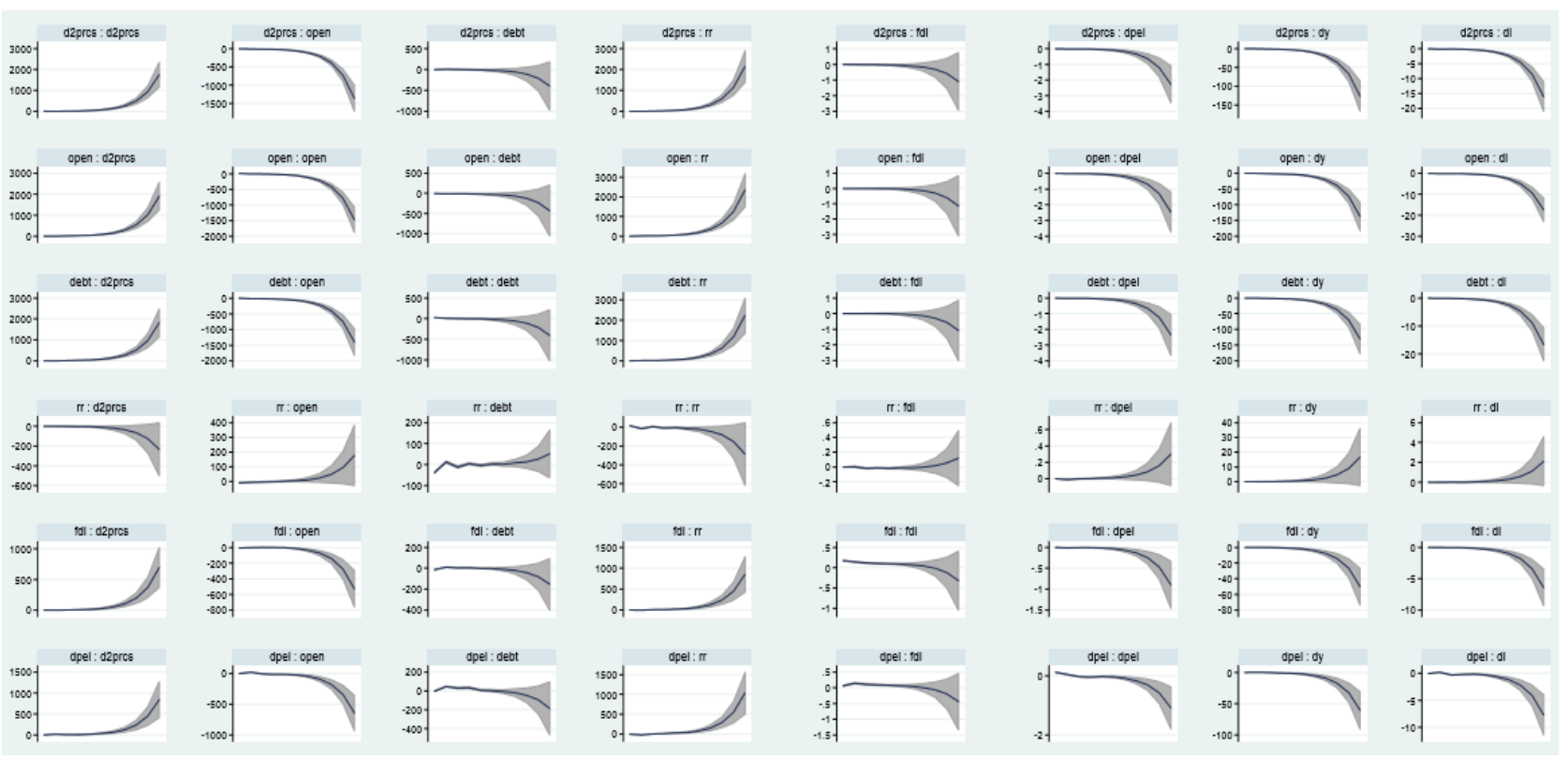

Figure 2. Impulse Response Functions (IRF)-case 2.

Source: Author's calculations from Stata15

The results from the impulse response function (Figure 2) show the effect of state sector investment on private investment, economic growth and on other variables for the following conclusions:

+ State sector investment (including public investment and SOE investments) have the effect of stimulating economic growth in the long term.

+ Domestic private investment and FDI investment stimulates economic growth in the short and medium term. In contrast, this investment is not to help economic growth in the long run

+ State sector investment has the effect of increasing public debt even in the medium and long term. This is very true of Vietnam's reality, as state sector investment has increased as public debt is rising.

+ State sector investment has the effect of crowding out the FDI investment and domestic private investment in the short and long term

+ State sector investment has decreased the amount of private investment capital stock (including both FDI and private investment capital stock) in the short term

+ State sector investment has the effect of increasing the economy's openness in the short and medium term

\section{Conclusions and Policy Implications for Public Investment and State Sector Investment in General in Vietnam}

The study used a quantitative method to assess the impact of public investment on private investment and economic growth based on data from 22 economic industries /sectors over a 27-year period (1990-2016) by applying PVAR model combined with GMM. The findings show that public investment affects private investment as well as has a spillover effect on GDP across most industries/sectors with varying effects cyclically and over time. In addition, private and SOE investments also have an impact on GDP cyclically or threshold effects (an inverted U-shape). The research also indicates that real interest rates (RRs), private capital stock(PRCs), economy openness (Open), and public debt (Debt), all have an impact on economic growth as shown in an inverted - U shape in medium term. In addition to studying the impact of public investment on private investment and economic growth (case 1), the study further examines the impact of state sector investment (case 2). The procedures and tools for case study 2 are the same as case one, but the results of the two cases are different because the nature of public investment is different from that of state sector investment. Because in Vietnam the government not only performs the role of providing public goods and services and investing in infrastructure to create favorable business environment to attract domestic private and FDI investments, but also directly involves in production and business activities through state-owned enterprises (SOEs). Through the history of development, Vietnam has shifted from a centrally planned economy to a market economy. In this process although the private sector has developed over the years, the state sector remains dominant. In order to see the difference between the effects of public investment and state sector investment on private investment and economic growth, below we will compare the results from the two cases above. 
The results of case 1 -analyzing the impact of public investment, and of case 2 - analyzing the impact of state sector investment (including public investment and SOE investments for production and business activities) show that when separating public investment from state sector investment, the impact of public investment (case 1) is more positive than the impact of state sector investment (case 2), specific:

(1) In terms of the impact on economic growth, the state sector investment creates the effect of long-term economic growth, while state sector investment creates more growth effects in the short term. This result implies that state-sector investment, including SOEs' investments in business activities, has a positive impact on economic growth in the short term and SOE's investment together with public investment has a resonance effect on economic growth in medium and long-term but the level of impact is weaker;

(2) In terms of the impact on domestic private and FDI investments, public investment has a stimulation and cyclical impact on private capital stock (domestic private + FDI capital stock). Public investment has the effect of boosting domestic private investment, FDI investment in the short and long term. Meanwhile, state-sector investment has decreased the amount of private capital stock in the short term, and crowds out domestic private and FDI investments in the short and long term;

(3) In terms of impact on other variables, both public investment and state sector investment has the effect of increasing public debt in the long term. Therefore, in the coming time, the government should set up the public investment and public expenditure framework for medium and long term, to avoid spreading investment to increase public investment efficiency

In general, our results are relatively consistent with previous studies, such as Barro's (1990) study or study in Asian developing countries by Phetsavong and Ichihashi (2012). According to this, public investment is often the investment in infrastructure that has the effect of attracting private investment and promoting economic growth. However, public investment is increasing public debt. This implies that government funding for public expenditure from state budget, usually made by tax increase or borrowing. It will negatively affect the private sector and economic growth. Therefore, public investment must be closely monitored to ensure transparency and efficiency. On the other hand, the impact factors have a threshold, which suggests that the government adjusts its policy of public investment, debt financing, and interest rate policy and investment environment in general to limit the impact in the down cycle.

The following part will give some implications and some more specific policy recommendations including:

First, it is clear that public investment is "bait" for private sector investment and a major driver of growth. However, through the analysis, public investment has a short cycle, therefore, to make public investment stable and become the leading factor, the government needs to have a long-term strategic investment plan that minimizes uncertainty (i.e., regulate to increase / decrease instability);

Second, public investment policy needs to be open and transparent. The lack of information in public investment has led to only temporary stimulus of private investment in the short term, in the medium term, there is a crowding-out private investment. In the long run, all information is clear, so public investment is likely to make the private sector investment increase and become more stable. These results also impact economic growth in a similar tendency;

Third, public investment and state sector investment increase public debt, so it is necessary to continue to restructure the state economic sector/ SOEs. Accordingly, reducing government intervention in the production business sector, promoting equitization, divesting state-owned enterprises from equitized SOEs, for increasing investment in infrastructure to reduce public debt, to create an investment environment that attracts domestic private investment and FDI capital, ultimately boosting economic growth.

\section{The Limitation of this Study and Suggestion for Further Research}

As mentioned above this study used PVAR model combined with GMM to assess the impact of public investment on private investment and economic growth based on data from 22 economic industries over a 27-year period (1990-2016). The findings show that public investment affects private investment as well as has a spillover effect on GDP across most industries with varying effects cyclically and over time. However, the study does not delve deeply into the role of public investment, private investment in each economic industry through inter-industrial impacts, as well as the impact of each industry on the economic growth as a whole in Vietnam.

Further research can be used another model to investigate the linkages across the economic industries or the structural relationships among the different industries of the economy and from this we can know the impact of each important industry on the economic growth in Vietnam

\section{Fund}

This research paper is funding by VNU-HCM budget with research project No B2016-34-01 


\section{References}

Abrigo, \& Love. (2015). Estimation of Panel Vector Auto regression in Stata: a Package of Programs. University of Hawaii working.

Bukhari, S., Ali, L., \& Saddaqat, M. (2007). Public Investment and Economic Growth in the Three Little Dragons: Evidence from Heterogeneous Dynamic Panel Data. International Journal of Business and Information.

Canova, F., \& Ciccarelli, M. (2013). Panel vector autoregressive models: A survey. ECB Working Paper 1507. https://doi.org/10.1108/S0731-9053(2013)0000031006

Cruz, B. O., \& Teixeira, R. J. (1999). The impact of public investment on private investment in Brazil 1947-1990. Cepal review, 67, $75-84$.

Cullison, E. W. (1993). Public Investment and Economic Growth. Federal Reserve Bank of Richmond Economic Quarterly, 79(4).

Dreger, C., \& Reimers, H. E. (2014). On the relationship between public and private investment in the euro area. Discussion Papers, DIW Berlin. https://doi.org/10.2139/ssrn.2403885

Dreger, C., \& Reimers, H. E. (2016). Does public investment stimulate private investment? Evidence for the euro area. Economic Modelling, 58, 154-158. https://doi.org/10.1016/j.econmod.2016.05.028

Erden, L., \& Holcombe, R. (2005). The effects of public investment on private investment in developing economies. Public Finance Review, 575 - 60. https://doi.org/10.1177/1091142105277627

Erden, L., \& Holcombe, R. (2006). The linkage between public and private investment: a co-integration analysis of a panel of developing countries. Eastern Economic Journal, 32(3), Summer 2006.

Foye, V. (2014). The impact of public capital spending on private investment in Nigeria. Journal of international academic research for multidisciplinary, 2(2).

Ghani, E., \& Din, M. (2006). The Impact of Public Investment on Economic Growth in Pakistan. The Pakistan Development Review, 45(1), 87-98.

Gjini, A., \& Kukeli, A. (2012). Crowding-Out Effect of Public Investment on Private Investment: An Empirical Investigation. Journal of Business \& Economics Research. https://doi.org/10.19030/jber.v10i5.6978

Greene, W. H. (2008). Econometric Analysis, 6th Edition. Upper Saddle River, NJ: Prentice-Hall.

Gregoriou, A., \& Ghosh, S. (2008). The Impact of Government Expenditure on Growth: Empirical Evidence from a Heterogeneous Panel. Economics and Finance, Brunel University.

Haque, S. (2013). Effect of Public and Private Investment on Economic Growth in Bangladesh: An econometric Analysis. Research Study Series No-FDRS.

Hatano. T. (2010). Crowding-in Effect of Public Investment on Private Investment. Policy Research Institute, Ministry of Finance, Japan, Public Policy Review.

Hsieh, E., \& Lai, N. (1994). Government spending and economic growth the G-7 experience. Review of Applied Economics, 26, 535-542. https://doi.org/10.1080/00036849400000022

Kao, C. (1999). Spurious regression and residual-based tests for co-integration in panel data. Journal of Econometrics 90, 1-44. https://doi.org/10.1016/S0304-4076(98)00023-2

Khan, M. (1996). Government Investment and Economic Growth in the Developing World. The Pakistan Development Review, 419-439.

Khan, M., \& Kumar, M. (1997). Public and private investment and the growth process in developing countries. Oxford Bulletin of Economics and Statistics, 59(1), 0305-9049. https://doi.org/10.1111/1468-0084.00050

Kollamparambil, U., \& Nicolaou, M. (2011). Nature and association of public and private investment: Public policy implications for South Africa. Journal of Economics and International Finance, 3(2), 98-108.

Kumo, W. (2012). Infrastructure Investment and Economic Growth in South Africa: A Granger Causality Analysis. Working Paper Series $N^{\circ} 160$ African Development Bank, Tunis, Tunisia.

Phetsavong, K., \& Ichihashi, M. (2012). The Impact of Public and Private Investment on Economic Growth: Evidence from Developing Asian Countries. IDEC Discussion paper, Hiroshima University.

Ramirez, M. D., \& Nazmi, N. (2003). Public Investment and Economic Growth in Latin America: An Empirical Test. Review of Development Economics, 7(1), 115-126. https://doi.org/10.1111/1467-9361.00179

Swaby, R. (2007). Public Investment and Growth in Jamaica. Fiscal and Economic Programme Monitoring Dept. - 
Bank of Jamaica.

To, T. T. (2011). Public investment "crowds out" private investment? A look from experimental model of VECM. Magazine of Finance, 6(560).

Tran, T. N. A., \& Le, P. H. (2014). Impact of public investment on economic growth in Vietnam: An experimental look of ARDL model. Development and Integration, 19, 3-10.

Vedder, \& Gallaway. (1998). Government size and economic growth- G-01 Dirksen Building, Washington, DC 20510, Phone: 202-224-5171, Fax: 202-224-0240, Internet Address: http://www.house.gov/jec/

Zainah, P. (2009). The Role of Public Investment in Promoting Economic Growth: A case study of Mauritius. SADRN/TIPS project.

\section{Appendix}

Appendix 1. List of Economic Industries/ Activities are classified by GSO-Vietnam

\begin{tabular}{l|l}
\hline Code & Kind of economic industry/activity \\
\hline 001 & Agriculture, \\
\hline 002 & Forestry \\
\hline 003 & Fishery \\
\hline 004 & Mining and quarrying \\
\hline 005 & Manufacturing \\
\hline 006 & Electricity, gas and hot water supply \\
\hline 007 & Water supply and waste disposal \\
\hline 008 & Construction \\
\hline 009 & Trade, repair of motor vehicles and household goods \\
\hline 010 & Transport, storage \\
\hline 011 & Hotels and restaurants \\
\hline 012 & Communications \\
\hline 013 & Finance, banking and insurance \\
\hline 014 & Real estate activities \\
\hline 015 & Professional activities, science and technology activities \\
\hline 016 & Administrative activities and assistant services \\
\hline 017 & Public administration, defense; compulsory security and socio-political organizations \\
\hline 018 & Training and education \\
\hline 019 & Health and social work activities \\
\hline 020 & Culture, sport and entertainment \\
\hline 021 & Other services activities \\
\hline 022 & $\begin{array}{l}\text { Activities of households as employers; undifferentiated goods and services producing activities of households } \\
\text { for own use }\end{array}$ \\
\hline
\end{tabular}


Appendix 2. The Result of Granger-Causality (case 1)

\begin{tabular}{|c|c|c|c|}
\hline \multicolumn{4}{|c|}{ Granger Test } \\
\hline Equation & Excuded & chi2 & Prob>chi2 \\
\hline \multirow[t]{9}{*}{ D.GI ${ }_{\text {it }}$} & D. $Y_{\text {it }}$ & 7907.07 & $0.00(*)$ \\
\hline & D.GEI ${ }_{i t}$ & 72.87 & $0.00(*)$ \\
\hline & D.PEI $_{i t}$ & 6994.16 & $0.00(*)$ \\
\hline & D.FDI $_{\mathrm{it}}$ & 22957.07 & $0.00(*)$ \\
\hline & $\mathrm{RR}_{\mathrm{it}}$ & 0.01 & $\underline{0.92}$ \\
\hline & Debt $_{\text {it }}$ & 0.29 & $\underline{0.58}$ \\
\hline & Open $_{\text {it }}$ & 122.44 & $\overline{0.00}(*)$ \\
\hline & $\mathrm{PRCS}_{\mathrm{it}}$ & 241.11 & $0.00(*)$ \\
\hline & ALL & 35473.45 & $0.00(*)$ \\
\hline \multirow[t]{9}{*}{ D. $Y_{i t}$} & D.GI ${ }_{i t}$ & 223.43 & $0.00(*)$ \\
\hline & D.GEI ${ }_{\mathrm{it}}$ & 8879.46 & $0.00(*)$ \\
\hline & D.PEI ${ }_{i t}$ & 8302.78 & $0.00(*)$ \\
\hline & D.FDI $_{\mathrm{it}}$ & 24837.32 & $0.00(*)$ \\
\hline & $\mathrm{RR}_{\mathrm{it}}$ & 16.91 & $0.00(*)$ \\
\hline & Debt $_{\text {it }}$ & 76.43 & $0.00(*)$ \\
\hline & Open $_{\text {it }}$ & 209.07 & $0.00(*)$ \\
\hline & $\mathrm{PRCS}_{\mathrm{it}}$ & 413.19 & $0.00(*)$ \\
\hline & ALL & 51921.62 & $0.00(*)$ \\
\hline \multirow[t]{9}{*}{ D.GEI ${ }_{\text {it }}$} & D. $Y_{i t}$ & 3876.53 & $0.00(*)$ \\
\hline & D. $\mathrm{GI}_{\mathrm{it}}$ & 2718.03 & $0.00(*)$ \\
\hline & D.PEI ${ }_{i t}$ & 7228.54 & $0.00(*)$ \\
\hline & D.FDI $_{\mathrm{it}}$ & 30605.57 & $0.00(* *)$ \\
\hline & $\mathrm{RR}_{\mathrm{it}}$ & 7170.22 & $0.00(*)$ \\
\hline & Debt $_{\text {it }}$ & 16.02 & $0.00(*)$ \\
\hline & Open $_{\text {it }}$ & 73.85 & $0.00(*)$ \\
\hline & $\mathrm{PRCS}_{\mathrm{it}}$ & 44.76 & $0.00(*)$ \\
\hline & ALL & 33236.89 & $0.00(*)$ \\
\hline \multirow[t]{9}{*}{ D.PEI $_{\text {it }}$} & D. $Y_{i t}$ & 299.18 & $0.00(*)$ \\
\hline & D. GI $\mathrm{it}_{\mathrm{t}}$ & 2798.46 & $0.00(*)$ \\
\hline & $\mathrm{GEI}_{\mathrm{it}}$ & 1286.87 & $0.00(*)$ \\
\hline & D.FDI $_{\mathrm{it}}$ & 4518.53 & $0.00(*)$ \\
\hline & $\mathrm{RR}_{\mathrm{it}}$ & 20.95 & $0.00(*)$ \\
\hline & Debt $_{\text {it }}$ & 30.69 & $0.00(*)$ \\
\hline & Open $_{\text {it }}$ & 161.41 & $0.00(*)$ \\
\hline & $\mathrm{PRCS}_{\mathrm{it}}$ & 44.76 & $0.00(*)$ \\
\hline & ALL & 9639.05 & $0.00(*)$ \\
\hline \multirow[t]{9}{*}{ D.FDI ${ }_{\text {it }}$} & D. $Y_{\text {it }}$ & 159.45 & $0.00(*)$ \\
\hline & D. GI ${ }_{\text {it }}$ & 1.25 & $\underline{0.26}$ \\
\hline & D.PEI ${ }_{i t}$ & 10360.26 & $\overline{0.00}(*)$ \\
\hline & $\mathrm{GEI}_{\mathrm{it}}$ & 2241.73 & $0.00(*)$ \\
\hline & $\mathrm{RR}_{\mathrm{it}}$ & 17.62 & $0.00(*)$ \\
\hline & Debt $_{\text {it }}$ & 65.11 & $0.00(*)$ \\
\hline & Open $_{\text {it }}$ & 82.24 & $0.00(*)$ \\
\hline & $\mathrm{PRCS}_{\text {it }}$ & 180.46 & $0.00(*)$ \\
\hline & ALL & 15650.49 & $0.00(*)$ \\
\hline
\end{tabular}

Source: Author's calculations from Stata15

$(*),(* *)$ Statistics those are significant at $1 \%$ level and $5 \%$ level 
Appendix 3. The Result of Granger-Causality Test (case 2)

\begin{tabular}{|c|c|c|c|}
\hline \multirow[t]{2}{*}{ Equation } & \multicolumn{3}{|c|}{ Granger Test } \\
\hline & Excuded & chi2 & Prob>chi 2 \\
\hline $\mathrm{I}_{\mathrm{it}}$ & $\begin{array}{l}\text { D.Y } \\
\text { D.PEI }_{\text {it }} \\
\text { D.FDI }_{i t} \\
\text { RR }_{\text {it }} \\
\text { Debt }_{i t} \\
\text { Open }_{\text {it }} \\
\text { PRCS }_{i t} \\
\text { ALL }\end{array}$ & $\begin{array}{l}6.39 \\
1057.75 \\
3683.56 \\
1.03 \\
0.02 \\
3.22 \\
308.06 \\
5203.71\end{array}$ & $\begin{array}{l}0.011(* *) \\
0.000(*) \\
0.000\left(^{*}\right) \\
\underline{\mathbf{0 . 3 1}} \\
\underline{\mathbf{0 . 8 8}} \\
0.07(* *) \\
0.00(*) \\
0.00\left(^{*}\right)\end{array}$ \\
\hline D. $Y_{i t}$ & $\begin{array}{l}\text { I }_{\text {it }} \\
\text { D.PEI }_{\text {it }} \\
\text { D.FDI }_{\text {it }} \\
\text { RR }_{\text {it }} \\
\text { Debt }_{\text {it }} \\
\text { Open }_{\text {it }} \\
\text { PRCS }_{\text {it }} \\
\text { ALL }\end{array}$ & $\begin{array}{l}154.77 \\
1996.97 \\
6825.54 \\
6.86 \\
19.34 \\
21.97 \\
122.02 \\
7604.05\end{array}$ & $\begin{array}{l}0.00(*) \\
0.00(*) \\
0.00(*) \\
0.09(* * *) \\
0.00(*) \\
0.00(*) \\
0.00(*) \\
0.00(*)\end{array}$ \\
\hline D.PEI ${ }_{i t}$ & $\begin{array}{l}\text { D.Y } \\
\text { I }_{\text {it }} \\
\text { D.FDI }_{\text {it }} \\
\text { RR }_{\text {it }} \\
\text { Debt }_{\text {it }} \\
\text { Open }_{\text {it }} \\
\text { PRCS }_{\text {it }} \\
\text { ALL }\end{array}$ & $\begin{array}{l}57.21 \\
936.62 \\
280.74 \\
0.41 \\
0.05 \\
13.07 \\
105.85 \\
1381.32 \\
\end{array}$ & $\begin{array}{l}0.00(*) \\
0.00(*) \\
0.00(*) \\
\underline{\mathbf{0 . 5 2}} \\
\underline{\underline{\mathbf{0 . 8 2}}} \\
0.00(*) \\
0.00(*) \\
0.00(*)\end{array}$ \\
\hline D.FDI $_{i t}$ & $\begin{array}{l}\text { D.Y } \\
\text { It } \\
\text { D.PEI }_{\text {it }} \\
\text { RR }_{\text {it }} \\
\text { Debt }_{\text {it }} \\
\text { Open }_{\text {it }} \\
\text { PRCS }_{\text {it }} \\
\text { ALL }\end{array}$ & $\begin{array}{l}125.72 \\
1809.91 \\
1803.03 \\
2.32 \\
3.25 \\
7.91 \\
161.72 \\
3502.71\end{array}$ & $\begin{array}{l}0.00(*) \\
0.00(*) \\
0.00(*) \\
\underline{\mathbf{0 . 1 2}} \\
0.07(* * *) \\
0.00(*) \\
0.00(*) \\
0.00(*)\end{array}$ \\
\hline
\end{tabular}

Source: Author's calculations from Stata15;

$(*),(* *),(* * *)$ Statistics those are significant at 1\% level, 5\% level, and $10 \%$ level

\section{Copyrights}

Copyright for this article is retained by the author(s), with first publication rights granted to the journal.

This is an open-access article distributed under the terms and conditions of the Creative Commons Attribution license which permits unrestricted use, distribution, and reproduction in any medium, provided the original work is properly cited. 